Article

\title{
Investigation of Flood Management and Mitigation Measures in Ungauged NATURA Protected Watersheds
}

\author{
Aristeidis Kastridis ${ }^{1, *(D)}$, Georgios Theodosiou ${ }^{2}$ and Georgios Fotiadis ${ }^{3}$ \\ 1 Laboratory of Mountainous Water Management and Control, School of Forestry and Natural Environment, \\ Aristotle University of Thessaloniki, 54124 Thessaloniki, Greece \\ 2 School of Forestry and Natural Environment, Aristotle University of Thessaloniki, 54124 Thessaloniki, Greece; \\ geothesty@for.auth.gr \\ 3 School of Forestry and Management of Natural Environment, Agricultural University of Athens, \\ 75 Iera Odos St., 11855 Athens, Greece; gefotiadis@aua.gr \\ * Correspondence: akastrid@for.auth.gr
}

Citation: Kastridis, A.; Theodosiou,

G.; Fotiadis, G. Investigation of Flood Management and Mitigation Measures in Ungauged NATURA Protected Watersheds. Hydrology 2021, 8, 170. https://doi.org/10.3390/ hydrology 8040170

Academic Editor: Ezio Todini

Received: 29 September 2021

Accepted: 11 November 2021

Published: 15 November 2021

Publisher's Note: MDPI stays neutral with regard to jurisdictional claims in published maps and institutional affiliations.

Copyright: (c) 2021 by the authors. Licensee MDPI, Basel, Switzerland. This article is an open access article distributed under the terms and conditions of the Creative Commons Attribution (CC BY) license (https:// creativecommons.org/licenses/by/ $4.0 /)$.

\begin{abstract}
The aim of this study is to investigate the flood management and mitigation measures in ungauged NATURA protected watersheds. The examined watersheds are located in one the most European significant NATURA areas (Prespa Natural Park North Greece). SCS-CN model was applied to perform the hydrological modeling for extreme rainfalls of 50,100 and 1000 return periods. Extensive field research was conducted to record all the hydrotechnical works of the study area, to evaluate their current condition and measure the respective hydraulic characteristics. The results of the hydrological modeling showed that the flood danger in the study area is generally low. However, almost the half of the hydrotechnical works could not discharge the high and medium probability (50 and 100 years) peak flows. The main causes are the extremely dense riparian vegetation that has been developed on the banks and the thalweg of the riverbeds and in some cases the inappropriate dimensioning of the technical works. The intense development of the riparian vegetation, has increased the roughness coefficient and reduced the dimensions and discharge capability of the technical works, while NATURA restrictions and regulations may be limiting any logging and trimming activities within the streams, especially in priority habitat types. Special Ecological Evaluation studies and educating the public about the necessity of the flood control measures and impact, could provide a framework for a thorough discussion about the flood management in NATURA areas.
\end{abstract}

Keywords: flood generation; hydrotechnical works; hydrological modeling; riparian vegetation; SCS-CN model

\section{Introduction}

Floods are natural phenomena that constitute an integral part of the hydrological cycle. Most floods are triggered by interactions between extreme unexpected weather events and the watershed geo-hydrological characteristics (relief, land uses, geomorphology, human interference) [1-4]. Floods in Mediterranean region could be considered to be the most often, destructive and hazardous natural phenomena, which usually occur in ephemeral streams and small-scale watersheds [5-8]. The last decades, floods have caused significant human fatalities [9-16] and noteworthy financial losses [10,17-20]. In Greece, as in the rest of Mediterranean area, a main factor that increases the potential of flood events is the human interventions such as urban sprawl [3,10,21-24], a fact that strongly influences the hydraulic characteristics of streams and floodplains $[10,25,26]$.

The investigation of extreme flood events in ungauged watersheds, using hydrological and hydraulic models, presents high uncertainties, because of the short lag time, the unexpected nature of flood phenomena and the lack of rainfall and discharge data $[10,25,27,28]$. For those reasons, the flood management is very complicated and difficult to be applied in ungauged watersheds. These difficulties are even more intense in NATURA protected 
watersheds, because of the special regulations and restrictions, concerning the management of the protected vegetation species and the strict rules of the construction/maintenance of hydrotechnical and flood control works $[29,30]$.

Natural lakes and reservoirs create special conditions for the breeding of wild life, but human interventions and land use changes could be a threat [31,32], downgrading the quality of the habitats. On the other hand, they are particularly important for the human activities such as water for irrigation, drinkable water, fishing, human recreation, etc. $[33,34]$.

The development of dense riparian forest in all the streams of the study area (Greek part of Prespa Natural Park basin) creates a special ecosystem of high ecological and aesthetic value. It also protects the slopes of the riverbeds from potential erosion [35]. The dense riparian forest consists mainly of large trees and shrubs, decisively influencing the roughness coefficient and favoring the sediment deposition. This fact results in a sharp decrease of water velocity and cross sections dimensions, reducing the discharge capability of the hydrotechnical works. The decision making, concerning the logging and trimming of the large trees and shrubs, the removal of sediment deposits from the banks and streams' thalweg, the construction of new flood control works and the maintenance of the old works, generates social conflicts among ecological groups, individual ecologists, local residents and local authorities, who suggest different flood management strategies to be applied.

The conflict between the scopes of the European Commission (EC) Water Framework Directive and the EC Habitats Directives (NATURA 2000) is known and generates conflict of interests among different people groups [36]. To the best of our knowledge there are few studies that deal with the flood risk management in NATURA protected areas [37,38], and there are very few that deal with ungauged NATURA protected small catchments [39], in which the zero-intervention strategy is applied within the floodplain area.

The aim of the study is to investigate the flood management in ungauged watersheds, which are under the protection of the NATURA regulations and restrictions, in the Greek Part of Prespa basin (GR 1340001). More specifically, (a) all the hydrotechnical works that influence the surface water flow were recorded, (b) the most flood vulnerable hydrotechnical works were located during the field work, (c) the stream maximum discharges were calculated for 50, 100 and 1000 return periods according to EU Directive (2007/60/EK), (d) the water discharge capability of each hydrotechnical work was calculated and evaluated in comparison to the stream maximum discharges, (e) the influence of NATURA regulations and restrictions that concern the construction and maintenance of the hydrotechnical works was discussed based on the study results.

\section{Materials and Methods}

\subsection{Study Area-Watersheds Description}

The importance of the Presa natural park (Figure 1) for the conservation of nature is really high. At its ecosystems one could find lots of rare species with some of them being endemic and appearing only at the Prespa lakes. More than 1800 plant species on 70 vegetation types, 270 bird species (of which 143 breed here) and lots of important fish, reptiles, amphibians and mammals can be found at the area. The district hosts a lot of endangered and threatened species on 49 different ecotypes in a restricted range where the diversity of altitude, land uses, climatic conditions and geological backgrounds is great $[35,40]$. Due to the wealth of the region, 4 different sites of the NATURA 2000 network have been designated. Prespa is also included at the Ramsar convention as a wetland of international importance. 


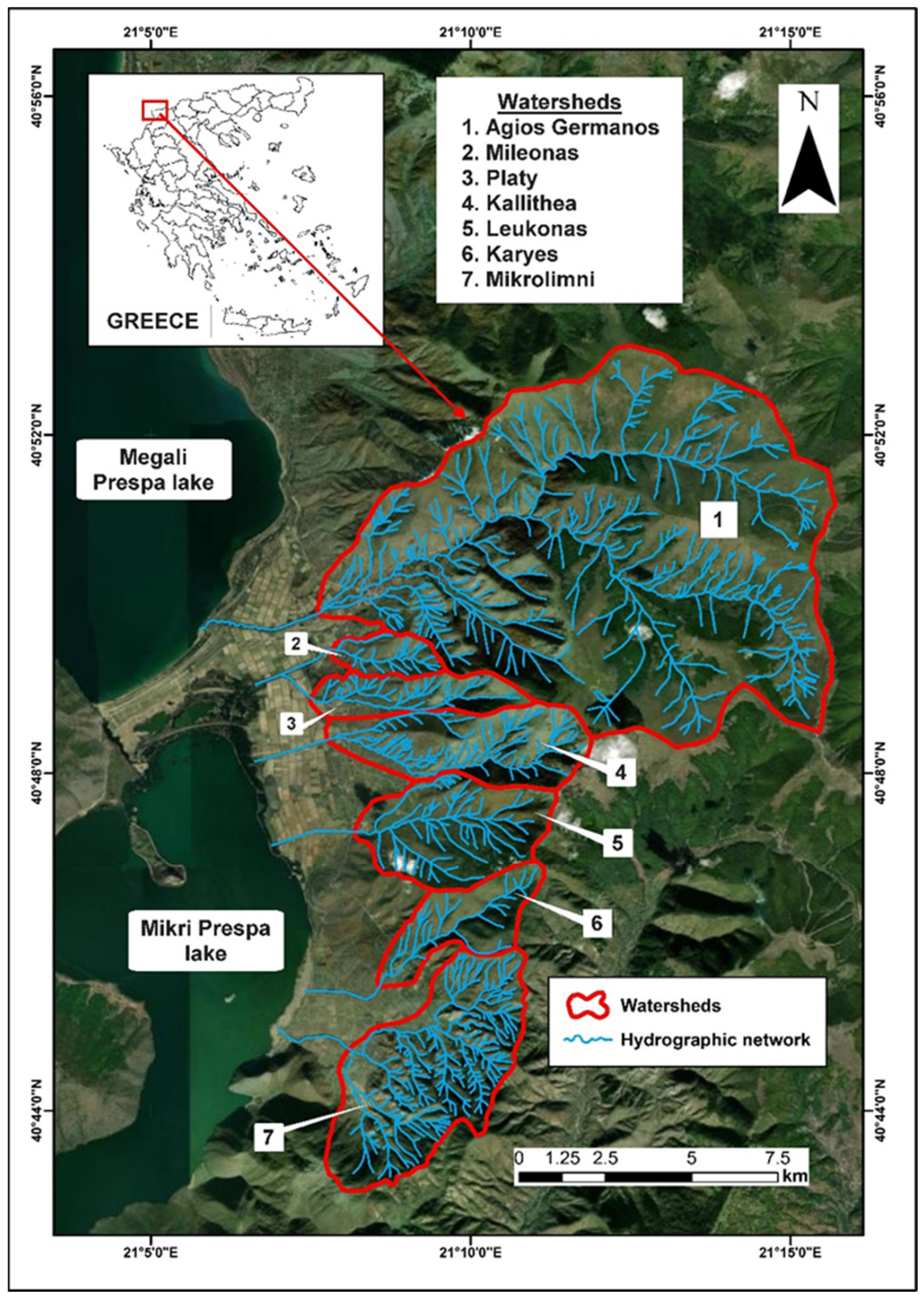

Figure 1. The watersheds that examined in the Greek part of Prespa Natural Park.

The dense forest vegetation that is growing on the stream banks and thalwegs of the study area, influences the flow of the flood water discharge, by increasing the roughness coefficient and decreasing the water velocity. Additionally, the dense forest vegetation traps significant amounts of sediments of various dimensions, which drastically decrease the stream cross sections dimensions, also decreasing the water discharge capability. The vegetation management within the stream banks and thalweg and the construction and maintenance of the technical works is very complicated, because the vegetation of the study area is part of the NATURA habitat types (Figure 2, 92A0-Salix alba and Populus alba galleries, 91E0-Alluvial forests with Alnus glutinosa and Fraxinus excelsior) [40,41]. As a result, any human intervention (flood management plans, flood control measures, construction and maintenance of the technical works) within the study area should be followed by a Special Ecological Evaluation study. 


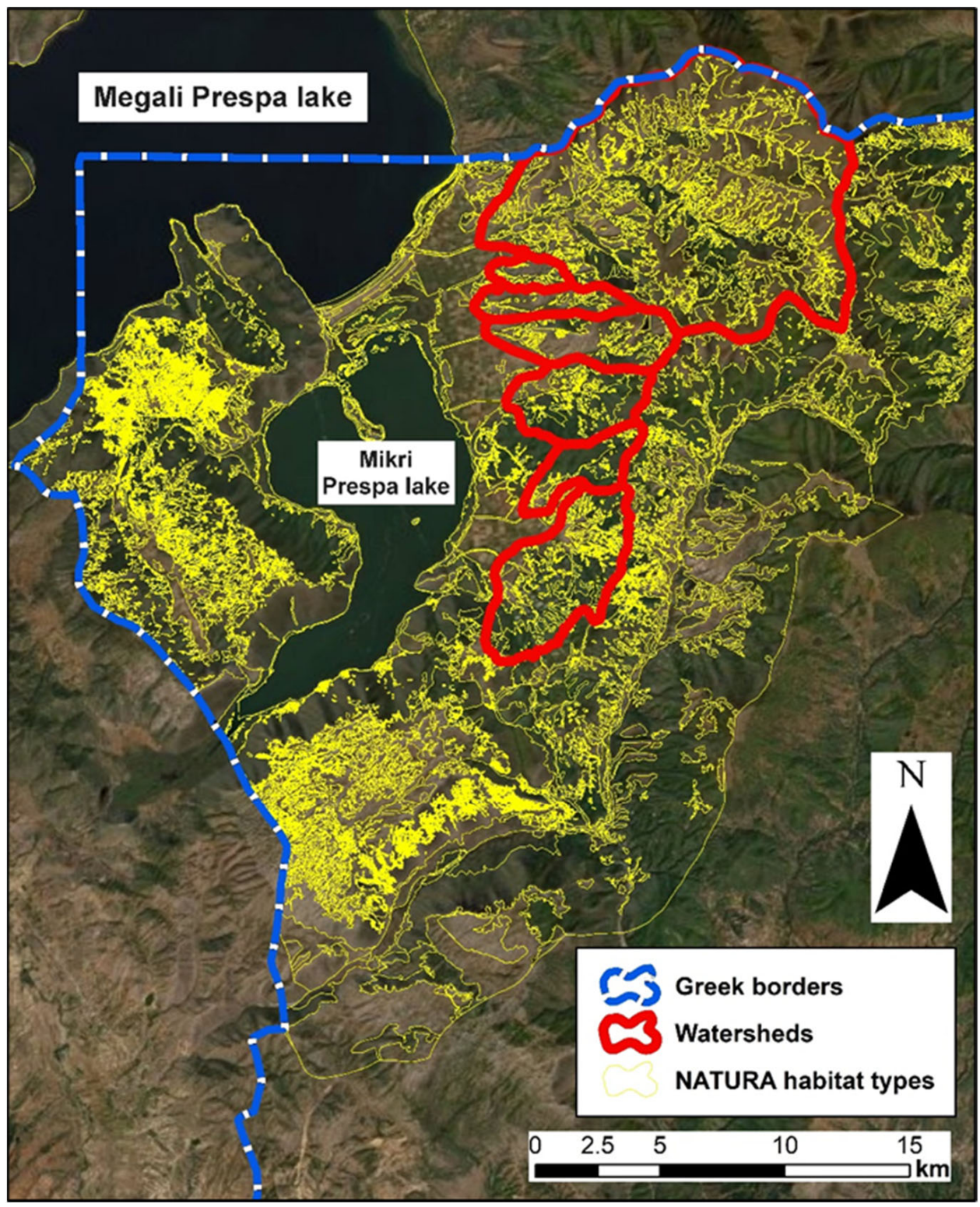

Figure 2. NATURA habitats types in the wider research area.

The hydrological modeling was applied in seven (7) typical Mediterranean watersheds, namely Agios Germanos, Mileonas, Platy, Kallithea, Leukonas, Karyes and Mikrolimni (Figure 1). These seven watersheds assigned with the respective settlement names, form the Greek part of the basin of the Prespa Natural Park. The total study area is $104.83 \mathrm{~km}^{2}$ and the headwaters of the main streams are located to Varnoudas (2334 $\mathrm{m}$ a.s.l.) and Moutsaras (2113 $\mathrm{m}$ a.s.1.) mountain ranges, the main streams flow generally with a west direction, pass through the above-mentioned settlements and finally flow into Prespa lakes. The relief of the watersheds could be characterized as mountainous and very steep, with an average slope over $42 \%$, but with significant differentiation between the floodplain and the areas above $1000 \mathrm{~m}$ a.s.l. In Table 1 the main watershed morphometric characteristics are presented. 
Table 1. Morphometric characteristics of the watersheds in the study area.

\begin{tabular}{|c|c|c|c|c|c|c|}
\hline & Area $\left(\mathbf{k m}^{2}\right)$ & Perimeter (km) & Min Altitude (m) & Max Altitude (m) & Mean Altitude (m) & $\begin{array}{c}\text { Mean Watershed } \\
\text { Slope (\%) }\end{array}$ \\
\hline Agios Germanos & 65.02 & 34.86 & 861 & 2334 & 1630 & 44.65 \\
\hline Mileonas & 1.85 & 6.01 & 873 & 1406 & 1049 & 39.96 \\
\hline Platy & 3.75 & 10.99 & 867 & 1970 & 1186 & 37.03 \\
\hline Kallithea & 7.88 & 13.54 & 878 & 2109 & 1358 & 47.34 \\
\hline Leukonas & 8.01 & 11.63 & 901 & 1835 & 1231 & 41.38 \\
\hline Karyes & 4.52 & 10.76 & 892 & 1675 & 1231 & 37.33 \\
\hline Mikrolimni & 13.80 & 16.86 & 863 & 1496 & 1068 & 40.78 \\
\hline
\end{tabular}

The $47.2 \%$ of the watersheds area is covered by grass land and pastures, $38.3 \%$ is covered by broad leaved and coniferous forests, $5.5 \%$ and $4.9 \%$ is covered by cropland and bare rocks, respectively, but with differentiation among the watersheds. The dominant rocks of the area are gneiss and granite, which behave as an impermeable formation to the water infiltration, and their participation exceeds the $90 \%$. Most of gneiss lithological types are easily weathered and covered by loose weathering mantle of ranging thickness, resulting in the manifestation of springs of usually low yield, in its contact with the intact rock [42]. The formation of the drainage network is mainly dendritic, the average density of drainage network is calculated to be $4.63 \mathrm{~km} / \mathrm{km}^{2}$ and the average main stream slope is $11.08 \%$ (Table 2). The density of the drainage network in the study area is relatively low, a fact that is attributed to the forest coverage and the extended presence of erosion resistant rocks (gneiss and granite).

Table 2. Hydrographic characteristics of the watersheds in the study area.

\begin{tabular}{|c|c|c|c|c|}
\hline & Drainage Network Formation & $\begin{array}{l}\text { Drainage Network } \\
\text { Density }\left(\mathbf{k m} / \mathrm{km}^{2}\right)\end{array}$ & $\begin{array}{l}\text { Main Stream } \\
\text { Length }(\mathbf{k m})\end{array}$ & $\begin{array}{c}\text { Main Stream Average } \\
\text { Slope }(\%)\end{array}$ \\
\hline Agios Germanos & Dendritic & 3.30 & 18.82 & 6.08 \\
\hline Mileonas & Dendritic & 5.30 & 4.47 & 10.89 \\
\hline Platy & Parallel & 4.52 & 6.27 & 15.21 \\
\hline Kallithea & Parallel & 5.07 & 8.27 & 14.69 \\
\hline Leukonas & Dendritic & 4.38 & 6.12 & 11.32 \\
\hline Karyes & Parallel & 4.14 & 6.44 & 11.80 \\
\hline Mikrolimni & Dendritic & 5.71 & 7.15 & 7.63 \\
\hline
\end{tabular}

\subsection{Estimation of the 24-h Maximum Rainfalls for 50, 100 and 1000 Years Return Periods}

The European Directive 2007/60/EC for the flood risk assessment, clarified that the flood risk should be calculated concerning the return periods of 50, 100 and 1000 years, estimating the respective Intensity-Duration-Frequency (IDF) rainfall curves. The calculation of IDF rainfall curves is a complex process, which requires the use of long rainfall time series, strict time step, reliable data and short recording time step (less than $6 \mathrm{~h}$ ). Unfortunately, there are no adequate and detailed rainfall data in the study area. To overcome this limitation, the time series of the daily maximum 24-h rainfall obtained from Koula Meteorological Station (MS) were used. Koula MS in operating continually for the last 64 years, and thus provides a significant time series length. However, Koula MS has only operated as an automated rain gauge with $30 \mathrm{~min}$ time step for the last seven years. Statistical analysis was implemented using the Hydrognomon software [43]. Initially, a quality control of the data was performed to identify potential extreme values that do not make sense, but also the dates on which missing values have been recorded. The missing values were substituted by applying the method of simple linear regression [44], 
using all the available time series of the broader study area. The error of the predicted values was calculated using well known statistic indexes, the Root Mean Square Error (RMSE), the Nash-Sutcliffe efficiency (NSE) and the Mean Bias Error (MBE). The Standard Deviation (SD) was calculated to be 5.97 and the RMSE was 3.17, almost the half of SD, which indicates an acceptable error range $[45,46]$. The NSE was 0.66 , which falls into the model acceptable range $(0-1)[45,46]$. The MBE was -0.98 , indicating an underestimation of the predicted values, which is totally normal, as the Koula rain gauge is located at a lower altitude and presents lower values of precipitation.

Statistical analysis was performed on time series data in order to calculate the $24 \mathrm{~h}$ max rainfall. The statistical distributions were subjected to $\chi^{2}$ test and Kolmogorov-Smirnov test to evaluate how well they were fitted to the time series, taking into account the concern about the influence of the time series length on distribution performance. The distribution that was best fitted to the time series was the GEV-max (Generalized Extreme Value-max; Figure 3 and Tables 3 and 4). According to the analysis, the maximum $24 \mathrm{~h}$ rainfalls for 50 , 100 and 100 years return periods were $77.4 \mathrm{~mm}, 84.9 \mathrm{~mm} \mathrm{k \alpha \iota} 108.9 \mathrm{~mm}$, respectively.

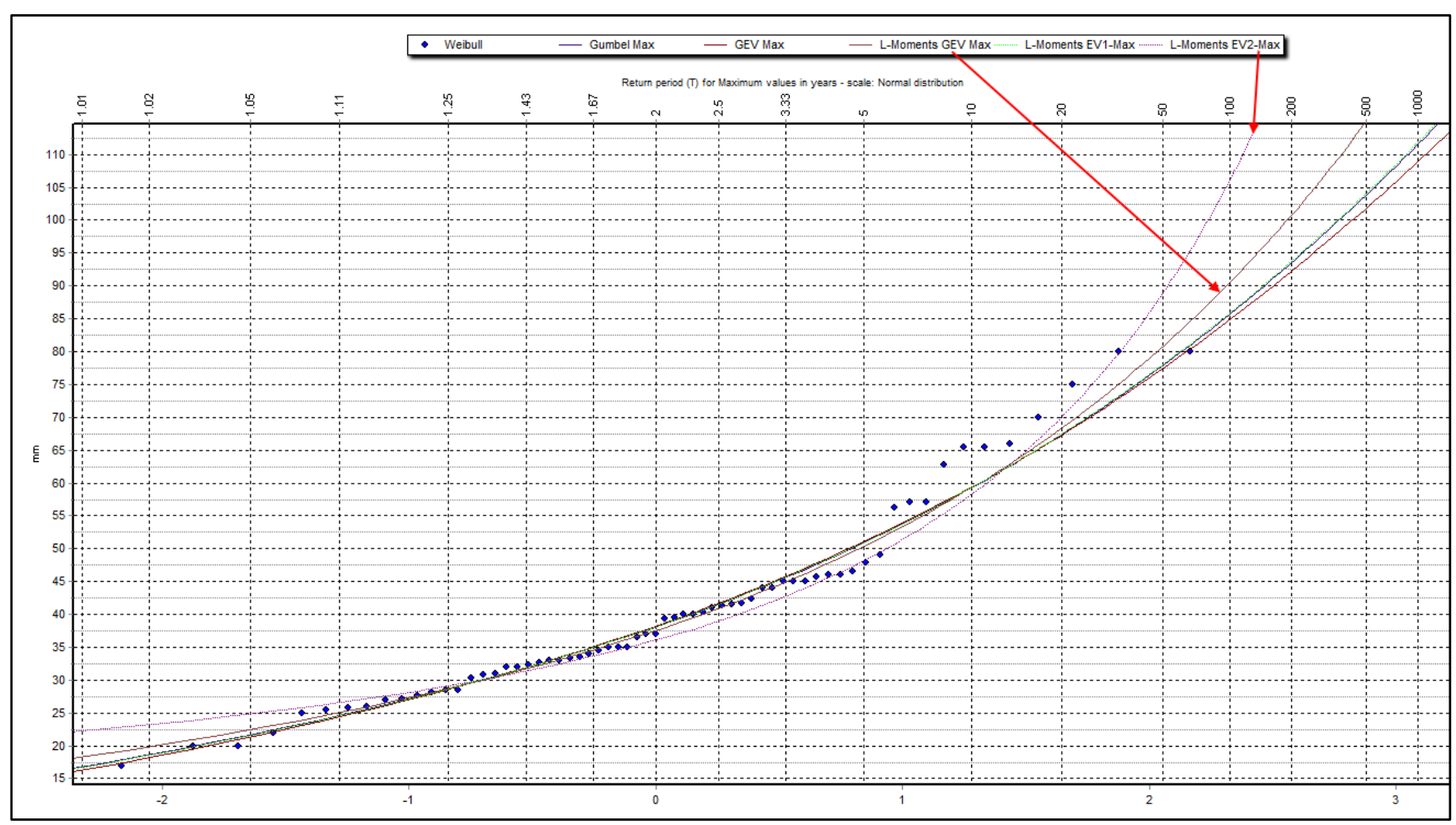

Figure 3. The 24-h maximum annual rainfalls depicted in a normal scatter plot with the tested distributions.

Table 3. Distributions' performance subjected to $\chi^{2}$ test.

\begin{tabular}{cccccc}
\hline x-Square Test & $\mathbf{a}=\mathbf{1} \%$ & $\mathbf{a}=\mathbf{5} \%$ & $\mathbf{a}=\mathbf{1 0} \%$ & Attained a & Pearson Param. \\
\hline EV1-Max (Gumbel max) & ACCEPT & ACCEPT & ACCEPT & $17.13 \%$ & 7.73846 \\
\hline GEV-Max & ACCEPT & ACCEPT & ACCEPT & $22.12 \%$ & 5.67692 \\
\hline GEV-Max (L-Moments) & ACCEPT & ACCEPT & ACCEPT & $21.71 \%$ & 5.76923 \\
\hline EV1-Max (Gumbel, L-Moments) & ACCEPT & ACCEPT & ACCEPT & $13.18 \%$ & 8.47692 \\
\hline EV2-Max (L-Moments) & ACCEPT & ACCEPT & ACCEPT & $13.18 \%$ & 8.47692 \\
\hline
\end{tabular}


Table 4. Distributions' performance subjected to Kolmogorov-Smirnov test.

\begin{tabular}{cccccc}
\hline Kolmogorov-Smirnov Test & $\mathbf{a}=\mathbf{1} \%$ & $\mathbf{a}=\mathbf{5} \%$ & $\mathbf{a}=\mathbf{1 0} \%$ & Attained a & DMax \\
\hline EV1-Max (Gumbel max) & ACCEPT & ACCEPT & ACCEPT & $92.35 \%$ & 0.06814 \\
\hline GEV-Max & ACCEPT & ACCEPT & ACCEPT & $93.71 \%$ & 0.05122 \\
\hline GEV-Max (L-Moments) & ACCEPT & ACCEPT & ACCEPT & $92.97 \%$ & 0.05484 \\
\hline EV1-Max (Gumbel, L-Moments) & ACCEPT & ACCEPT & ACCEPT & $91.93 \%$ & 0.06865 \\
\hline EV2-Max (L-Moments) & ACCEPT & ACCEPT & ACCEPT & $57.55 \%$ & 0.09686 \\
\hline
\end{tabular}

\subsection{Disaggregation of the 24-h Maximum Rainfalls for 50, 100 and 1000 Years Return Periods}

To perform the hydrological simulation in the study area, it was necessary to disaggregate the calculated values of the 24-h maximum rainfalls (50, 100 and 1000 years return periods). The disaggregation was achieved applying the SCS storm types (I, IA, II, III), compiled by the Soil Conservation Service [47]. To decide which of the four storm types was best fitted on the available storm data from Koula MS, a comparison with known extreme events was applied. During the field research, residents and local authorities were asked if they had witnessed flood events in the past. Based on this information, an extreme flood event was recorded on August 3, 2015 between 17:00 and 19:00, which could be confirmed by the available meteorological data. The total recorded rainfall was $55.8 \mathrm{~mm}$ with duration of $2 \mathrm{~h}$. The total rainfall $(55.8 \mathrm{~mm})$ was disaggregated using the SCS storm types for $2 \mathrm{~h}$ duration [48] and compared with the observed rainfall data (Figure 4).

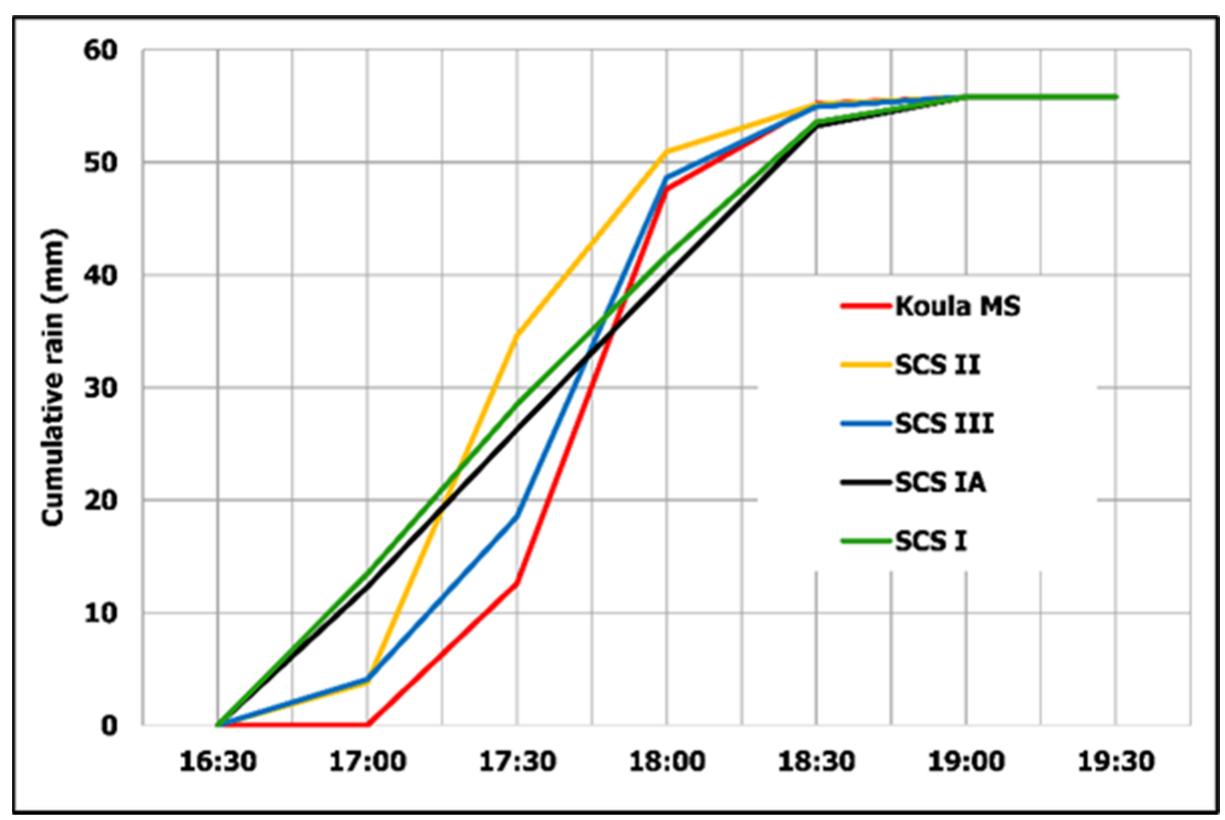

Figure 4. Disaggregated cumulative rainfall event (3 August 2015, 55.8 mm) using SCS storm types (I, IA, II, III) compared with the observed data (Koula MS).

\subsection{Hydrological Modeling}

The hydrological modeling was applied for the seven watersheds of the study area, using the rainfall-runoff model of Soil Conservation Service-Curve Number (SCS-CN) [47]. SCS-CN hydrological model is well-known and widely used in many countries [49-53] and also in Greece [54-60]. The Curve Number (CN) is a dimensionless empirical parameter used for the estimation of runoff and infiltration from rainfall excess, and ranges from 30 to 100 , with the highest values indicating higher runoff potential. 
The Hydrologic Engineering Center's Hydrologic Modeling System (HEC-HMS) software [61] was implemented to calculate the flood hydrographs for 50, 100 and 1000 years return periods. The basic components of HEC-HMS software ( $\mathrm{CN}$, impervious area, transform method, base flow method, initial abstraction, lag time, loss method, etc.) were set as follows: CN (loss method), no baseflow method (ephemeral streams) and SCS unit hydrograph (transform method) were applied. The initial abstraction and the respective $\mathrm{CN}$ were modified according to Antecedent Moisture Conditions (AMC) and the flood hydrographs for each watershed and return period were calculated two times, one for AMCII and one for AMCIII, in order to cover the worst flood scenarios. SCS considers that there are three categories of Antecedent Moisture Conditions (AMC), which are Type I (dry), Type II (medium) and Type III (wet). These are defined based on cumulative rainfall thresholds of the previous five days, as shown in Table 5.

Table 5. Categorization of rainfall of the previous 5 days for the calculation of the initial rainfall losses of the SCS-CN method [62].

\begin{tabular}{ccc}
\hline \multirow{2}{*}{ AMC Group } & \multicolumn{2}{c}{ Total 5-Day Antecedent Rainfall (mm) } \\
\cline { 2 - 3 } & Dormant Season & Growing Season \\
\hline I & Less than 13 & Less than 35 \\
\hline II & $13-28$ & $35-53$ \\
\hline III & Over 28 & Over 53 \\
\hline
\end{tabular}

The SCS-CN model was previously calibrated and validated in other relevant studies in Greece, which presented similar geomorphologic and land-use conditions [26,55].

The dimensionless empirical parameter CNII,20 (for AMC II average humidity conditions and an initial loss rate 20\%) was estimated using GIS techniques and the empirical equation provided by the "Deucalion Project", which has been validated in Mediterranean watersheds [63]:

$$
\text { CNII,20 }=10+9 \times \mathrm{iPERM}+6 \times \mathrm{iVEG}+3 \times \mathrm{iSLOPE}
$$

where iPERM (water permeability), iVEG (land uses-vegetation density) and iSLOPE (drainage capability) are variables that receive values ranging between 1 and 5 , according to the related tables $[63,64]$ and field research. The iPERM was based on the dominant type of building constructions, soil and geological characteristics of the watersheds, which were estimated using the geological maps $(1: 50,000)$ provided by the Institute of Geology and Mineral Exploration of Greece [42] (map sheets: Florina and Korytsa), as well as field surveys. The vegetation variable (iVEG) was estimated using the detail data that are available from the Greek Ministry of Environment and Energy [41]. A Digital Elevation Model (DEM, $5 \times 5 \mathrm{~m}$ resolution) provided by the Hellenic Cadastre was used, in order for the iSLOPE variable to be estimated.

Humidity conditions II and the corresponding CNII values are considered to be representative of $50 \%$ of the flood episodes. However, during the winter season when the soil is almost permanently saturated, the CNII value does not correspond to the real conditions. For this reason, the value corresponding to average humidity conditions (type II) should be converted to the initial soil moisture conditions type III according to the empirical relation [62]:

$$
\text { CNII,20 }=(23 \mathrm{CNII}, 20) /(10+0.13 \mathrm{CNII}, 20)
$$


Concerning the time of concentration $\left(t_{c}\right)$, previously published studies refer that Giandotti equation is more reliable in the Greek and Mediterranean watershed conditions $[64,65]$. For that reasons, Giandotti equation [66] was selected to be used in order to calculate the time of concentration $\left(t_{c}\right)$ :

$$
\mathrm{t}_{\mathrm{c}}=\frac{4 \sqrt{\mathrm{F}}+1.5 \mathrm{~L}}{0.8 \sqrt{\mathrm{H}-\mathrm{h}}}
$$

where, $t_{c}$ : the time of concentration (hours), $F$ : watershed area $\left(\mathrm{km}^{2}\right), \mathrm{L}$ : the main stream length $(\mathrm{km}), \mathrm{H}$ : average altitude $(\mathrm{m})$.

The lag time $\left(t_{L}\right)$ was calculated in relation to the time of concentration $(t c)$ using the following equation [67]:

$$
\mathrm{t}_{\mathrm{L}}=0.6 \times \mathrm{t}_{\mathrm{c}}
$$

where, $t_{\mathrm{L}}$ : the lag time (hours) and $\mathrm{t}_{\mathrm{c}}$ : the time of concentration (hours)

\subsection{Field Work-Maximum Water Discharge Capability of the Technical Works}

The main purpose of the field survey was the detailed recording of the technical works that were associated with the surface water runoff in the watersheds and the influence on the maximum water discharge. Additionally, using information provided by the residents and the local authorities, the flood vulnerable locations and technical works were recorded. The current conditions, dimensions, Manning's roughness coefficient and stream slope of the selected technical works (bridges, culverts, water pipes) that discharge the water peak flow were measured and the maximum discharge capability was calculated. These hydrotechnical works presented limited dimensions, poor maintenance and their locations (near settlements, infrastructures, livestock, road network) are characterized by high flood risk, and in case of flood event significant human life and socioeconomic losses could be emerged. The hydraulic characteristics of the selected cross sections are presented in Table 6.

Using the measured hydraulic characteristics of the selected cross sections of the technical works, the maximum water discharge capability was calculated applying the Manning equation [68]:

$$
\begin{gathered}
\mathrm{u}=1 / \mathrm{n} \times \mathrm{R}^{2 / 3} \times \mathrm{J}^{1 / 2} \\
\mathrm{Q}=\mathrm{F} \times \mathrm{u}
\end{gathered}
$$

where, $\mathrm{u}$ : water velocity $(\mathrm{m} / \mathrm{s}), \mathrm{R}$ : hydraulic radius $(\mathrm{R}=\mathrm{F} / \mathrm{U}), \mathrm{F}$ : cross section area $\left(\mathrm{m}^{2}\right)$, U: cross section wetted perimeter $(\mathrm{m})$, J: energy grade line slope $(\mathrm{m} / \mathrm{m})$, $\mathrm{n}$ : Manning's roughness coefficient [69] and Q: water discharge $\left(\mathrm{m}^{3} / \mathrm{s}\right)$

During the field survey, the vegetation that was growing near the technical works, on the banks and the thalwegs of the streams was recorded, with the aim to evaluate the influence of vegetation on the maximum water discharge. According to the field survey and the habitat types (Council Directive 2006/105/EC), all the vegetation types in the study area are under the protection of the NATURA regulations and restrictions. 
Table 6. Hydraulic characteristics and the water velocity of the examined cross sections.

\begin{tabular}{|c|c|c|c|c|c|c|c|c|c|}
\hline & & $\begin{array}{l}\text { Cross Section } \\
\text { Width (m) }\end{array}$ & $\begin{array}{l}\text { Cross Section } \\
\text { Height }(\mathrm{m})\end{array}$ & $\begin{array}{c}\text { Slope J } \\
(\mathrm{m} / \mathrm{m})\end{array}$ & $\begin{array}{c}\text { Wetted } \\
\text { Perimeter U (m) }\end{array}$ & $\begin{array}{l}\text { Manning's Roughness } \\
\text { Coefficient }(n)\end{array}$ & $\begin{array}{l}\text { Cross Section } \\
\text { Area }\left(\mathrm{m}^{2}\right)\end{array}$ & $\begin{array}{c}\text { Hydraulic } \\
\text { Radius R (m) }\end{array}$ & $\begin{array}{c}\text { Water Velocity } \\
\mathbf{u}(\mathrm{m} / \mathrm{s})\end{array}$ \\
\hline 1 & $\begin{array}{l}\text { Agios Germanos } \\
\text { (AG18-bridge) }\end{array}$ & 7.70 & 2.30 & 0.0440 & 12.0 .033 & 0.028 & 17.71 & 1.44 & 9.36 \\
\hline 2 & $\begin{array}{l}\text { Agios Germanos } \\
\text { (LE6-culvert) }\end{array}$ & 2.80 & 2.00 & 0.0340 & 6.80 & 0.04 & 5.60 & 0.82 & 4.05 \\
\hline 3 & $\begin{array}{l}\text { Agios Germanos } \\
\text { (LE3-culvert) }\end{array}$ & 3.50 & 1.70 & 0.0530 & 6.90 & 0.04 & 5.95 & 0.86 & 5.21 \\
\hline 5 & $\begin{array}{l}\text { Agios Germanos } \\
\text { (YP9-culvert) }\end{array}$ & 4.00 & 2.70 & 0.0807 & 9.40 & 0.028 & 10.80 & 1.15 & 10.91 \\
\hline 6 & $\begin{array}{l}\text { Agios Germanos } \\
\text { (YP7-bridge) }\end{array}$ & 6.60 & 2.10 & 0.0760 & 10.80 & 0.04 & 13.86 & 1.28 & 8.14 \\
\hline 7 & $\begin{array}{c}\text { Mileonas } \\
\text { (MH2-concrete pipe) }\end{array}$ & \multicolumn{2}{|c|}{2 concrete pipes with $1 \mathrm{~m}$ diameter } & 0.0110 & 3.14 & 0.033 & 0.78 & 0.25 & 1.25 \\
\hline 9 & $\begin{array}{c}\text { Kallithea } \\
\text { (KA8-culvert) }\end{array}$ & 5.50 & 1.20 & 0.0850 & 7.90 & 0.04 & 6.60 & 0.84 & 6.47 \\
\hline 10 & Leukonas (L4-bridge) & 10.00 & 2.40 & 0.0480 & 14.80 & 0.04 & 24.00 & 1.62 & 7.54 \\
\hline 11 & Karyes (K2-culvert) & 4.00 & 2.00 & 0.0740 & 8.00 & 0.04 & 8.00 & 1.00 & 6.80 \\
\hline 12 & Karyes (K6-culvert) & 2.00 & 1.00 & 0.0720 & 4.00 & 0.033 & 2.00 & 0.50 & 5.09 \\
\hline 13 & 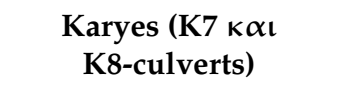 & 2.50 & 1.00 & 0.0720 & 4.50 & 0.033 & 2.50 & 0.56 & 5.46 \\
\hline 14 & $\begin{array}{l}\text { Mikrolimni } \\
\text { (M20-culvert) }\end{array}$ & 2.90 & 1.00 & 0.0229 & 4.90 & 0.033 & 2.90 & 0.59 & 3.21 \\
\hline 15 & $\begin{array}{l}\text { Mikrolimni } \\
\text { (M8-culvert) }\end{array}$ & 2.10 & 1.70 & 0.01 & 5.50 & 0.033 & 3.57 & 0.65 & 2.67 \\
\hline
\end{tabular}




\section{Results and Discussion}

\subsection{Technical Works Recording-Maximum Discharge Capability Estimation}

In Figure 5 the recorded technical works of the study area are presented. It is obvious and also expected, that most of the hydrotechnical works were constructed at the junctions between the road and hydrographic network.

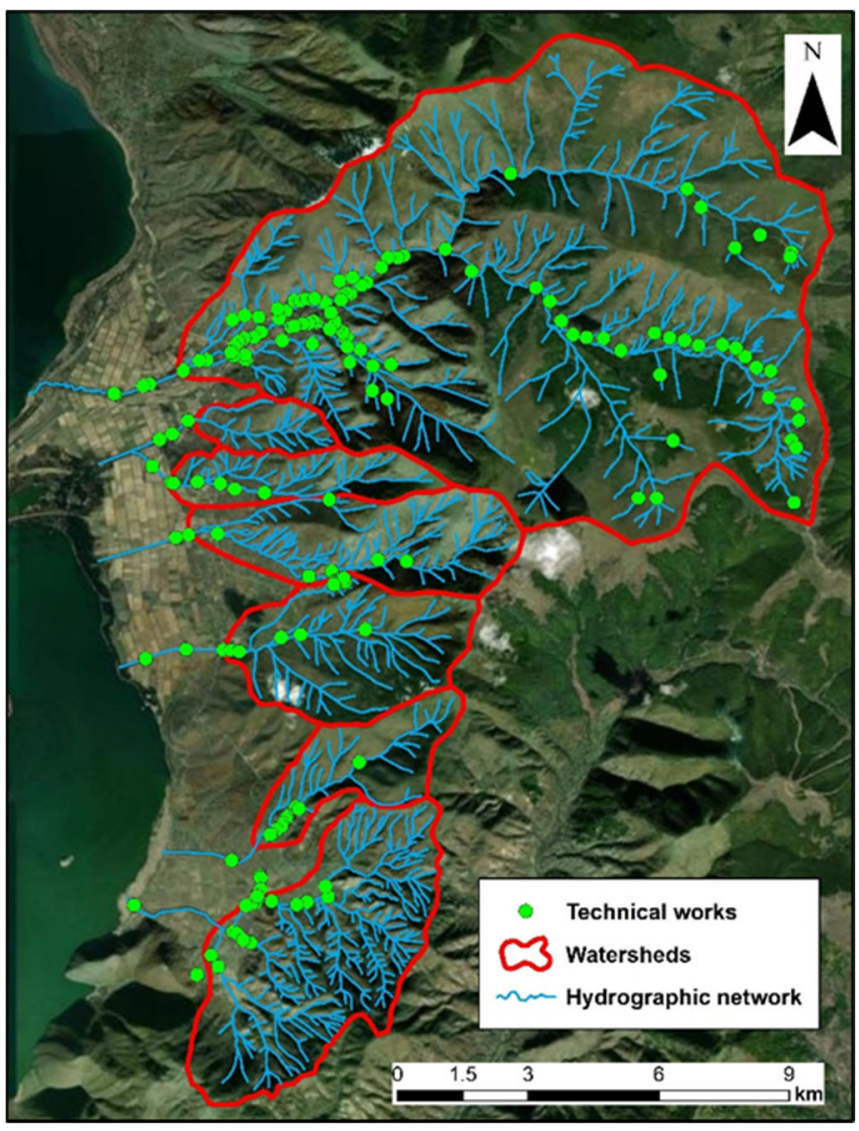

Figure 5. The location of the recorded hydrotechnical works within the study area.

Additionally, in Table 7 the categories and the number of technical works for each watershed are presented. Table 7 revealed that the majority of the technical works (bridges and culverts, $66 \%$ ) have a direct relation with the discharge of the flood peak flows.

Table 7. Total recordings of all the existing hydrotechnical works in the research area.

\begin{tabular}{|c|c|c|c|c|c|c|c|c|c|}
\hline & $\begin{array}{l}\text { Records for Each } \\
\text { Watershed }\end{array}$ & Bridge & $\begin{array}{l}\text { Pedestrian } \\
\text { Bridge }\end{array}$ & $\begin{array}{c}\text { Water } \\
\text { Pumping }\end{array}$ & $\begin{array}{l}\text { Check } \\
\text { Dams }\end{array}$ & $\begin{array}{l}\text { Concrete } \\
\text { Culverts }\end{array}$ & $\begin{array}{l}\text { Plastic } \\
\text { Culverts }\end{array}$ & $\begin{array}{l}\text { Concrete } \\
\text { Stream } \\
\text { Sections }\end{array}$ & $\begin{array}{c}\text { Other } \\
\text { Technical } \\
\text { Works }\end{array}$ \\
\hline Agios Germanos & 98 & 15 & 6 & 8 & 10 & 40 & 8 & 5 & 6 \\
\hline Mileonas & 3 & 1 & 0 & 0 & 0 & 1 & 1 & 0 & 0 \\
\hline Platy & 8 & 3 & 0 & 0 & 3 & 0 & 0 & 0 & 2 \\
\hline Kallithea & 18 & 4 & 0 & 1 & 11 & 0 & 1 & 0 & 1 \\
\hline Leukonas & 7 & 4 & 0 & 0 & 0 & 0 & 2 & 0 & 1 \\
\hline Karyes & 12 & 3 & 0 & 1 & 1 & 5 & 0 & 0 & 2 \\
\hline Mikrolimni & 19 & 1 & 2 & 0 & 2 & 12 & 0 & 1 & 1 \\
\hline Sum & 165 & 31 & 8 & 10 & 27 & 58 & 12 & 6 & 13 \\
\hline
\end{tabular}


During the field survey, the condition of the technical works was evaluated, while the most flood prone locations/works were recorded. This evaluation was based on the following criteria: (a) the proximity with settlements, houses and important infrastructures, (b) the existence of dense vegetation and trapped sediments and (c) the hydraulic characteristics of the cross sections, In Figure 6 the most flood prone locations/works are depicted and in Table 6 there are the respective hydraulic characteristics of each location/work.

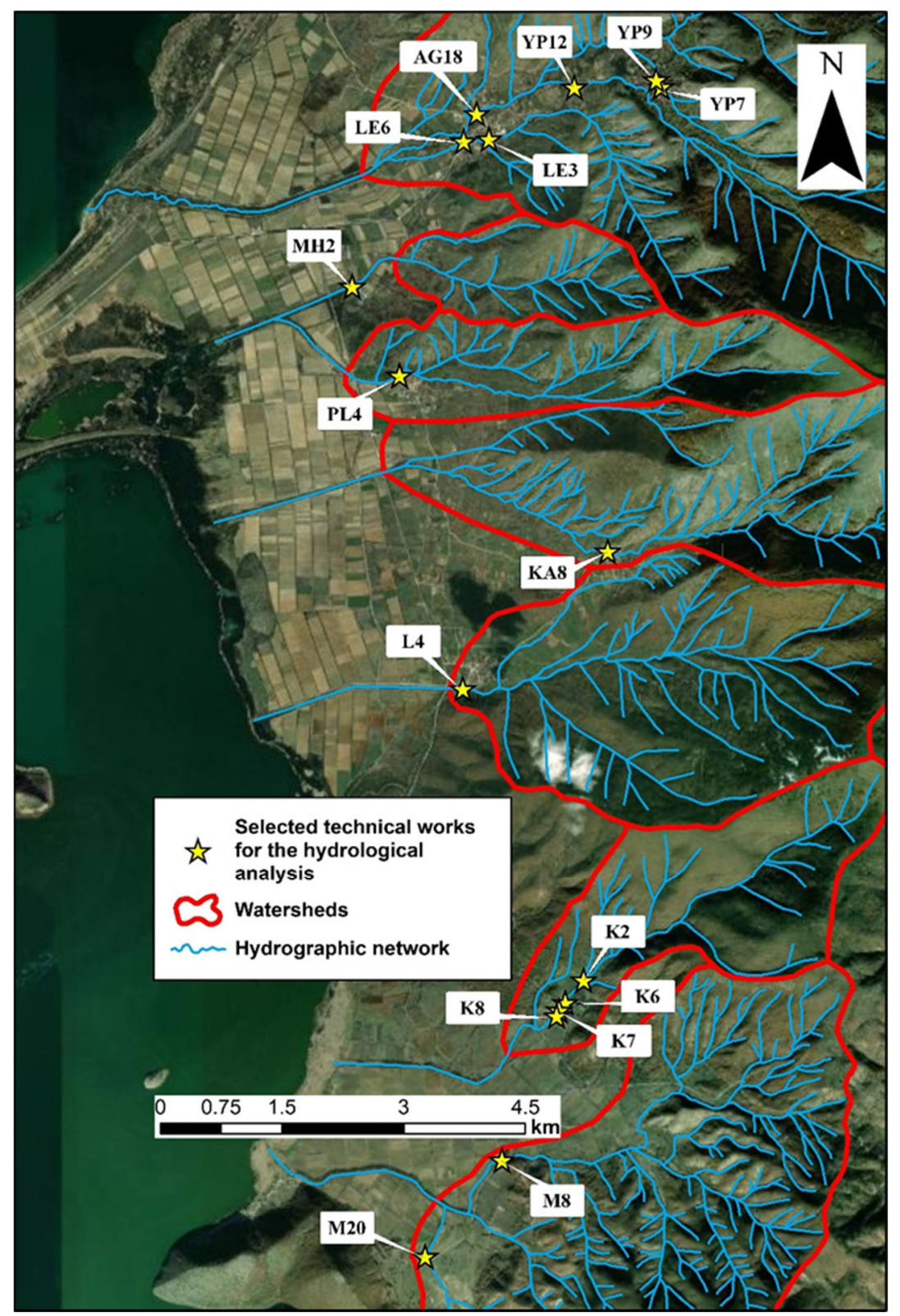

Figure 6. Location and coding of the selected technical works that were used for the hydrological analysis.

\subsection{Curve Number (CN) and Time of Concentration $\left(t_{c}\right)$ Estimation-Hydrological Modeling}

Figure 7 shows the spatial distribution of the CNII,20 parameter, while Table 8 shows the mean values of the CNII,20 and CNIII parameters for all the watersheds in the research area. CNIII values were resulted applying the Equation (2). Figure 7 depicts increased values of the CNII,20 parameter, which are attributed to the increased average slope of the study area, low water permeability of the geological formations of the area (gneiss, granite) and the relatively low cover by forest vegetation. 


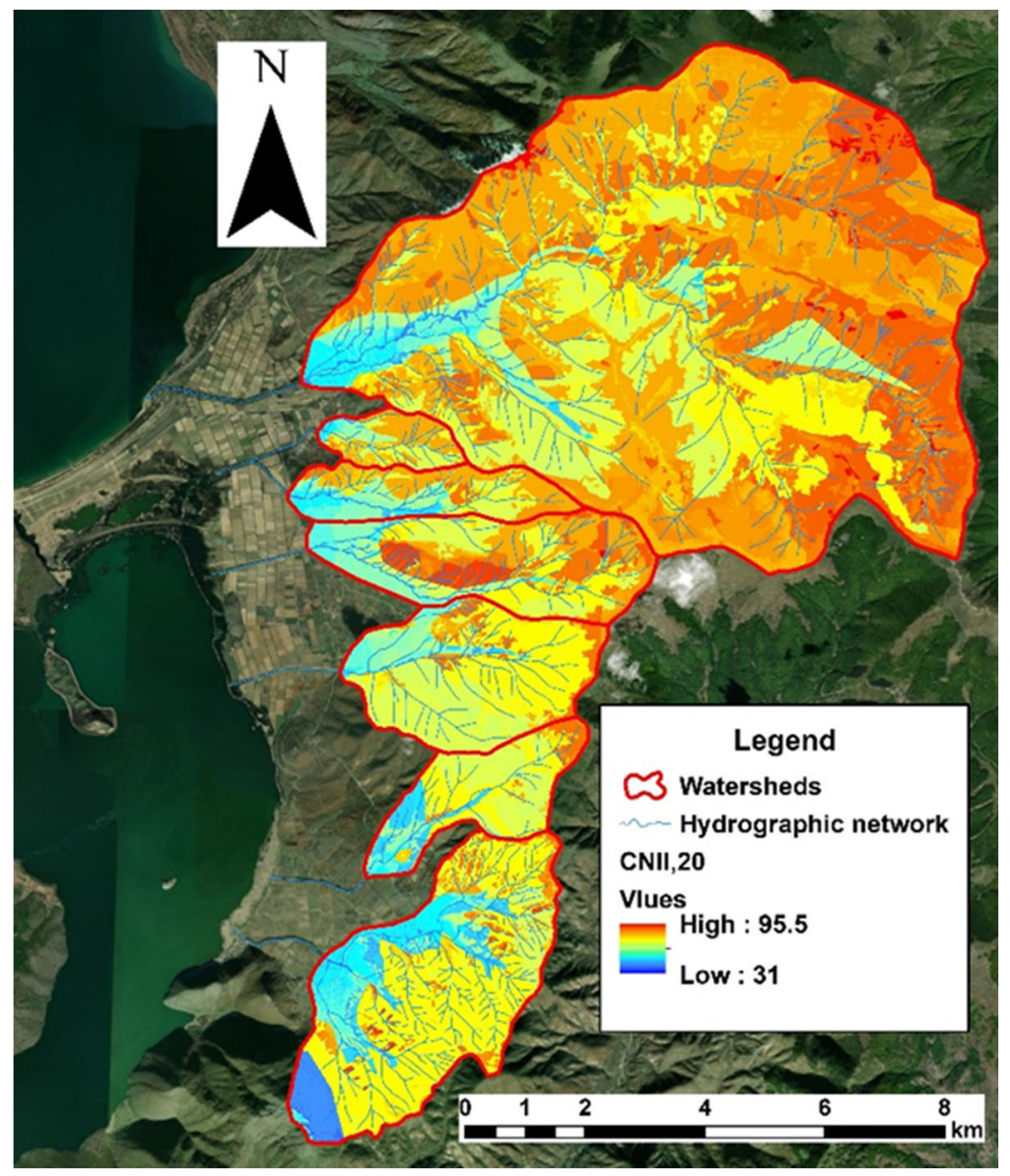

Figure 7. Spatial distribution of the CNII,20 for AMCII in the watersheds of the study area.

Table 8. CNII,20 and CNIII mean value for all the watersheds.

\begin{tabular}{ccc}
\hline Watersheds & CNII,20 & CNIII \\
\hline Agios Germanos & 80.34 & 90.12 \\
\hline Mileonas & 73.94 & 86.71 \\
\hline Platy & 70.91 & 84.86 \\
\hline Kallithea & 75.51 & 87.64 \\
\hline Leukonas & 71.05 & 84.95 \\
\hline Karyes & 68.31 & 83.22 \\
\hline Mikrolimni & 67.99 & 83.01 \\
\hline
\end{tabular}

The values CNII,20 and CNIII are relatively high and particularly those of CNIII (over 80), which means that in wet conditions (mainly in winter and autumn) the risk of flooding is increased, due to the reduced capability of soil and vegetation to retain large amounts of precipitation. It is known that forests present finite capabilities to retain large amounts of precipitation, especially during extreme rainfall events [70], even if the forest cover percentage is significantly high $[22,55]$. It is evident, that the AMC plays a crucial role in the flood generation and in the study area the flood risk potential is very high especially in wet conditions (AMCIII).

In Table 9, the results of the calculated values of Giandotti time of concentration and lag time are presented. The watersheds presented similar values of time of concentration mainly because of the similar values of hydrographic and morphometric characteris- 
tics, with an exception in Agios Germanos and Mikrolimni watersheds, which exhibited higher values.

Table 9. Hydrographic and morphometric characteristics required for the calculation of Giandotti time of concentration and lag time.

\begin{tabular}{|c|c|c|c|c|c|c|}
\hline & Area & Min Altitude & Mean Altitude & $\begin{array}{l}\text { Main Stream } \\
\text { Length }\end{array}$ & $\begin{array}{c}\text { Time of } \\
\text { Concentration Giandotti }\end{array}$ & $\begin{array}{c}\text { Lag Time } \\
\text { (USDA) }\end{array}$ \\
\hline \multirow{2}{*}{ Units } & $\mathrm{km}^{2}$ & $\mathrm{~m}$ & $\mathrm{~m}$ & $\mathrm{~km}$ & $\mathrm{~h}$ & $\min$ \\
\hline & $\mathrm{F}$ & Hmin & Hmed & $\mathrm{L}$ & $t_{c}$ & $t_{L}$ \\
\hline Agios Germanos & 65.02 & 861 & 2334 & 18.82 & 1.970 & 70.92 \\
\hline Mileonas & 1.85 & 873 & 1049 & 4.47 & 1.144 & 41.20 \\
\hline Platy & 3.75 & 867 & 1186 & 6.27 & 1.200 & 43.21 \\
\hline Kallithea & 7.88 & 878 & 1358 & 8.27 & 1.348 & 48.54 \\
\hline Leukonas & 8.01 & 901 & 1231 & 6.12 & 1.411 & 50.78 \\
\hline Karyes & 4.52 & 892 & 1231 & 6.44 & 1.233 & 44.39 \\
\hline Mikrolimni & 13.8 & 863 & 1068 & 7.15 & 2.234 & 80.41 \\
\hline
\end{tabular}

In Table 10, the maximum discharge capability of the selected hydrotechnical works and the peak discharges for 50,100 and 1000 return periods of the respective streams are presented. According to the results, there are many cases of the selected hydrotechnical works that are proven not sufficient to discharge the expected peak flows for the examined return periods. Specifically, in Table 10 the red values (red cells) indicate the circumstances, in which the technical works will fail to discharge the expected peak flows. The marginal cases are marked in orange, while the cases, in which the technical works will discharge the expected peak flows are presented in green color. Accepting the known uncertainties of the hydrological models in ungauged watersheds, the marginal values were based on a reasonable range between $\pm 20 \%$, which could be characterized as acceptable in hydrological modeling $[10,56,71,72]$.

Table 10. Maximum discharge capability of the technical works and the stream peak flow for 50, 100 and 1000 years return periods.

\begin{tabular}{|c|c|c|c|c|c|c|c|}
\hline & \multirow{3}{*}{$\begin{array}{l}\text { Maximum Discharge } \\
\text { Capability of the } \\
\text { Technical Works } Q\left(\mathrm{~m}^{3} / \mathrm{s}\right)\end{array}$} & \multicolumn{6}{|c|}{ Stream Peak Flow $\left(\mathrm{Q} \mathrm{m}^{3} / \mathrm{s}\right)$} \\
\hline & & \multicolumn{3}{|c|}{ AMC II } & \multicolumn{3}{|c|}{ AMC III } \\
\hline & & 50 Years & 100 Years & 1000 Years & 50 Years & 100 Years & 1000 Years \\
\hline $\begin{array}{l}\text { Agios Germanos } \\
\text { (AG18-bridge) }\end{array}$ & 165.79 & 157.00 & 187.80 & 295.50 & 259.00 & 294.40 & 412.50 \\
\hline Agios Germanos (LE6-culvert) & 22.68 & 9.90 & 12.10 & 19.90 & 18.20 & 20.90 & 29.80 \\
\hline Agios Germanos (LE3-culvert) & 31.02 & 8.27 & 10.11 & 16.63 & 15.21 & 17.47 & 24.91 \\
\hline Agios Germanos (YP12-culvert) & 6.55 & 14.80 & 18.40 & 31.60 & 30.00 & 34.60 & 50.30 \\
\hline Agios Germanos (YP9-culvert) & 117.79 & 3.20 & 4.00 & 6.80 & 6.70 & 7.70 & 11.20 \\
\hline Agios Germanos (YP7-bridge) & 112.81 & 3.20 & 4.00 & 6.80 & 6.70 & 7.70 & 11.20 \\
\hline Mileonas (MH2-concrete pipe) & 0.98 & 5.00 & 6.20 & 10.50 & 10.10 & 11.60 & 16.80 \\
\hline Platy (PL4-culvert) & 72.77 & 7.90 & 10.00 & 18.00 & 18.30 & 21.20 & 31.30 \\
\hline Kallithea (KA8-culvert) & 42.72 & 15.30 & 18.80 & 31.10 & 28.90 & 33.20 & 47.60 \\
\hline Leukonas (L4-bridge) & 180.86 & 15.50 & 19.70 & 35.30 & 36.00 & 41.80 & 61.70 \\
\hline Karyes (K2-culvert) & 54.41 & 7.50 & 9.90 & 18.60 & 20.10 & 23.60 & 35.40 \\
\hline Karyes (K6-culvert) & 10.19 & 7.50 & 9.90 & 18.60 & 20.10 & 23.60 & 35.40 \\
\hline Karyes (K7 к $\alpha \iota$ K8-culverts) & 13.65 & 7.50 & 9.90 & 18.60 & 20.10 & 23.60 & 35.40 \\
\hline Mikrolimni (M20-culvert) & 9.31 & 4.92 & 6.43 & 12.19 & 13.29 & 15.60 & 23.58 \\
\hline Mikrolimni (M8-culvert) & 9.53 & 8.53 & 11.14 & 21.12 & 23.01 & 27.03 & 40.85 \\
\hline
\end{tabular}




\subsection{The Influence of the NATURA Restrictions and Regulations on Flood Management Measures}

The results revealed that the specific peak flow ranged between 2.5 and $7.8 \mathrm{~m}^{3} / \mathrm{s} / \mathrm{km}^{2}$, values which internationally, and in Greece, are considered relatively low for flood danger potential. Usually, values of specific peak flow between 9 and $11 \mathrm{~m}^{3} / \mathrm{s} / \mathrm{km}^{2}$ are considered dangerous and can cause severe flooding $[10,55,73]$. Thus, the area can be considered as of low flood risk in terms of flood peak flows.

The Greek legislation considers that the small dimension and low importance technical works should be constructed to be capable to discharge the maximum discharges of 50 and 100 years return period for AMCII. The results showed that almost the half of the technical works of the study area could not discharge the high and medium probability (50 and 100 years) flood peak flows.

The main causes that directly affects and dramatically reduces the maximum discharge capability of the technical works are the extremely dense riparian vegetation that has been developed on the banks and the thalweg of the riverbeds and in some cases the inappropriate dimensioning of the technical works. This vegetation consists mainly of NATURA protected trees and shrubs of large size and in high density. The development of dense riparian forest in all the riverbeds of the region creates a special ecosystem of high ecological and aesthetic value, which is protected by NATURA regulations. It also protects the banks of the streams from potential erosion. However, the strict restrictions on trees/shrubs logging and trimming within the streams, have caused the unlimited development of the riparian vegetation around and sometimes on the technical works and along the streams and also the concentration of large amounts of sediments in various locations. This situation significantly increased the roughness coefficient and reduced the dimensions of the technical works cross sections. In many cases, the dense vegetation and the sediments have blocked to a large extent the openings of the technical works, while it is characteristic that in few cross sections the dimensions of the cross sections were not measured, because access was impossible. In Figure 8 the condition of the technical works is indicatively presented.
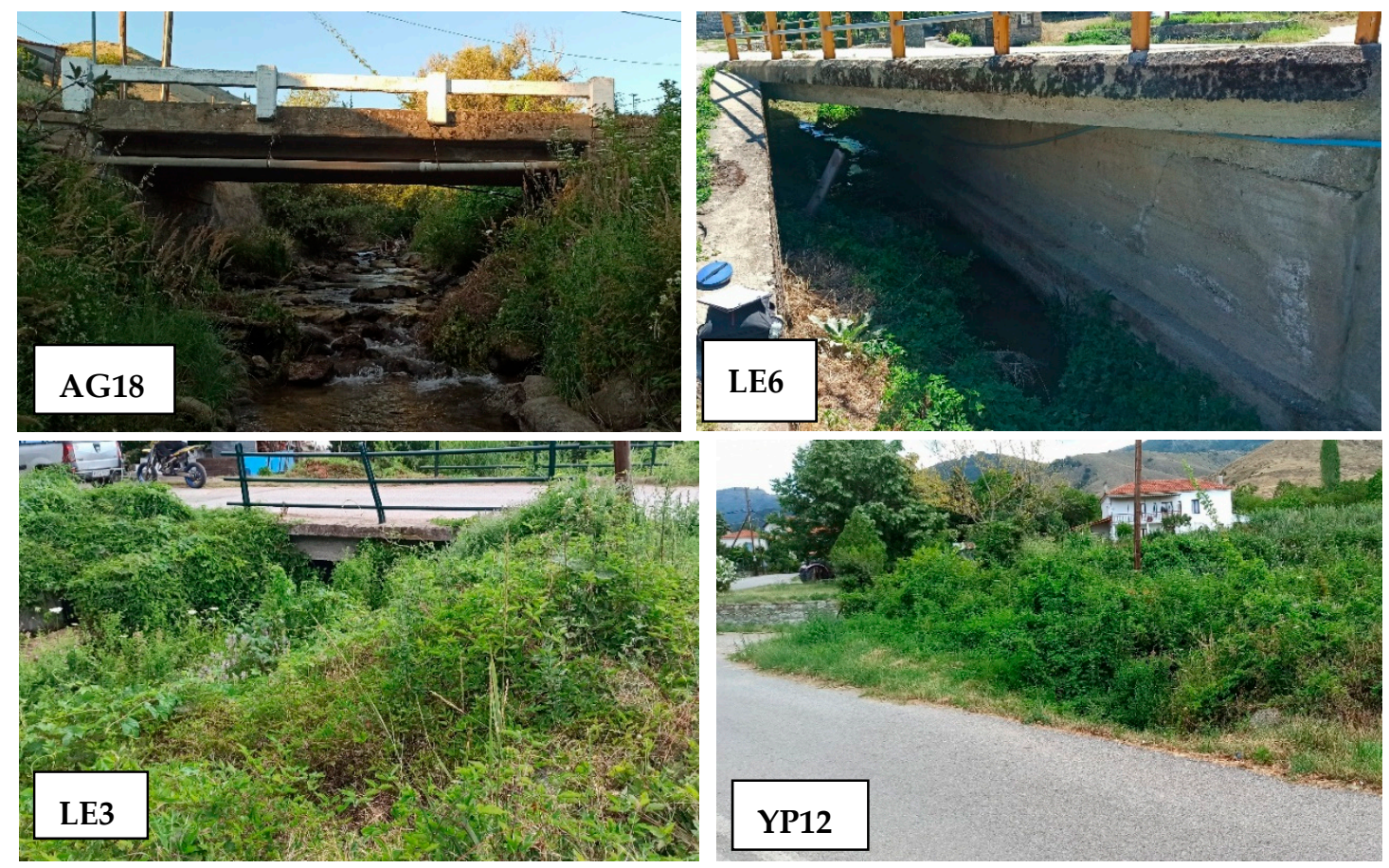

Figure 8. Cont. 

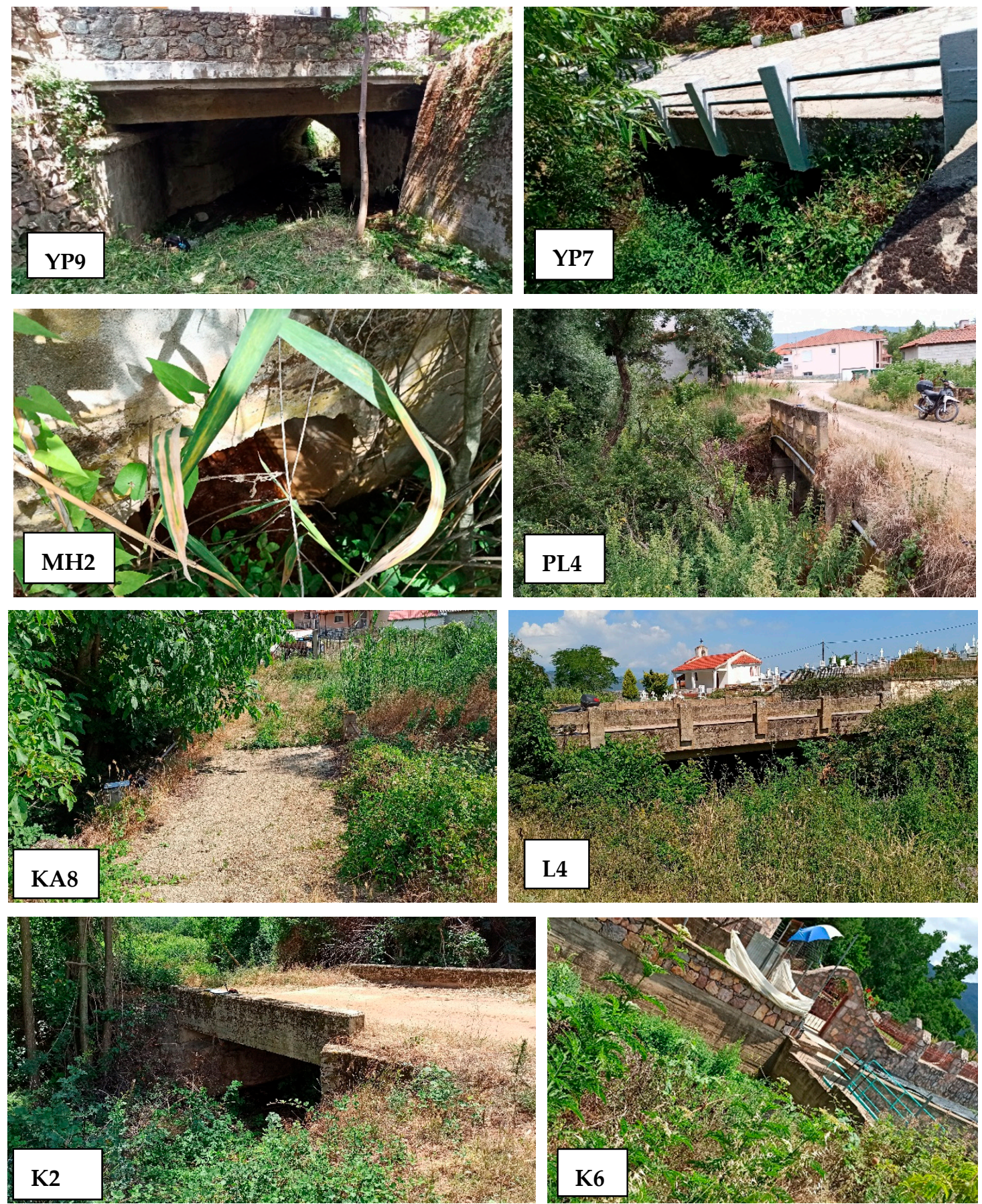

Figure 8. Cont. 

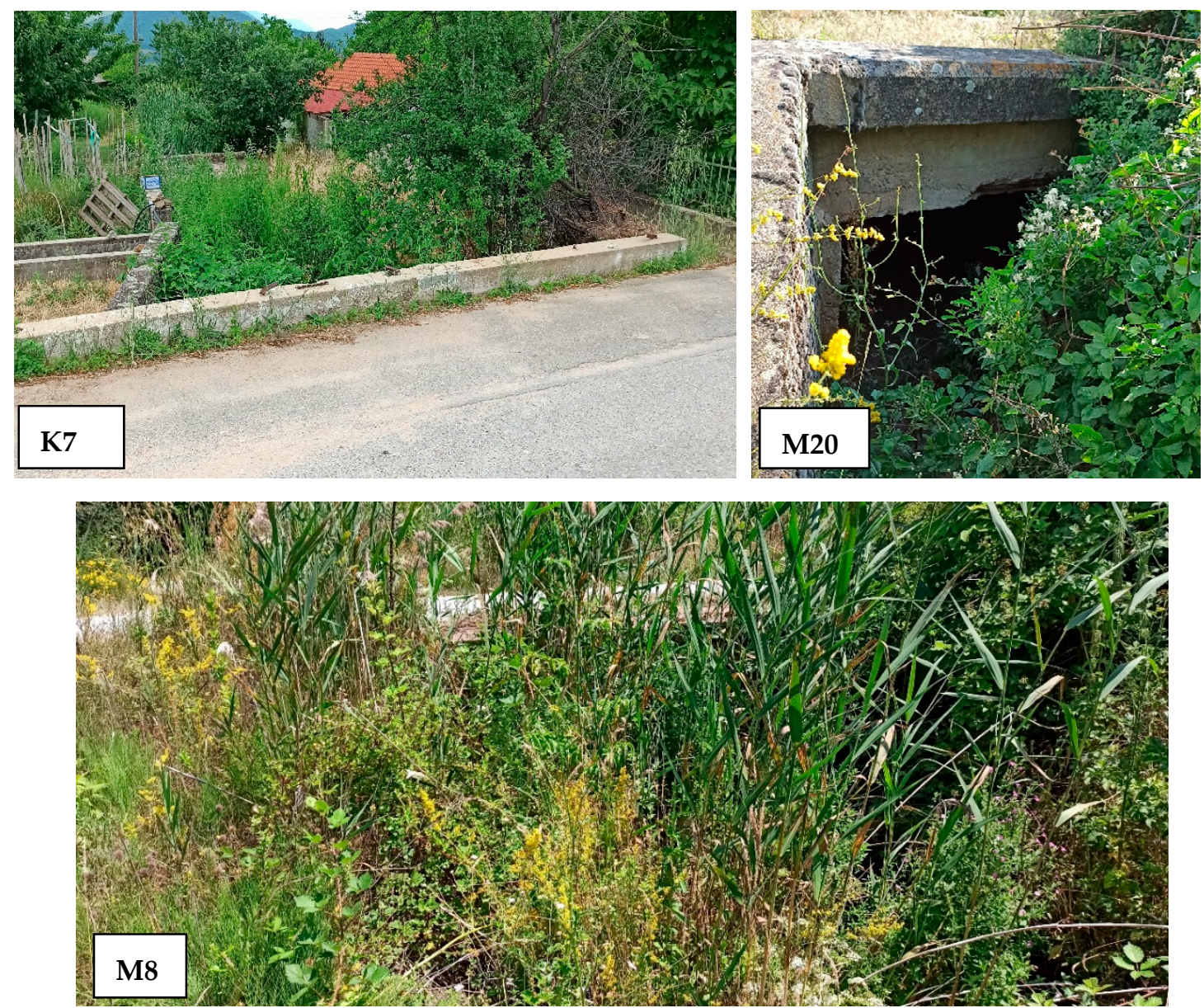

Figure 8. Representative pictures of the selected hydrotechnical works for the hydrological analysis. (AG18):bridge; (LE6):culvert; (LE3):culvert; (YP12):culvert; (YP9):culvert; (YP7):bridge; (MH2):concrete pipe; (PL4):culvert; (KA8):culvert; (L4):bridge; (K2):culvert; (K6):culvert; (K7):culvert; (M20):culvert; (M8):culvert.

The creation of flood management plan, the construction of new flood control works, the maintenance and/or reconstruction of the old technical works, the logging and trimming of trees and shrubs, the sediment depletion of streams, require a Special Ecological Evaluation study, complying with NATURA regulations and the Greek legislation requirements. The Special Ecological Evaluation study is subjected to public consultation, where every individual person or group can erase arguments. Prespa National Park Management Body (PNPMB) is the authority responsible for activities such as wetland management, providing information and raising awareness, protecting the area and guarding against illegal activities such as unlicensed sand extraction and hunting which place a stress on the natural environment. Society for the Protection of Prespa (SPP) participate as a member of the Board of Directors, but has also actively supported the work of the PNPMB. The PNPMB, SSP, the forest service, Ministry of Environment and Energy (YPEN) and local authorities (Municipality) are the main stakeholders who should collaborate in order to plan the vegetation management is streams and the flood management and control measures. Various ecological groups and ecologists are active in the research area, which are extremely sensitive to the NATURA habitat protection, and frequently just for the trimming of some shrubs and branches several difficulties and obstacles are encountered. This fragmentation of flood risk management, among many services, combined with the sensitivity of many ecologists to the logging and trimming of trees and shrubs, has led to the deterioration of the maintenance/reconstruction of hydrotechnical works and the lack of flood control management plan, a fact which increase the flood risk in the study area. 


\section{Conclusions}

The results of the maximum 24-h rainfalls for return periods of 50, 100 and 1000 showed that the rainfall intensity in the study area is generally low and as a result the potential of flood generation is also low. The hydrological analysis and the value of the specific peak discharge revealed also that the flood risk in the examined watersheds is low. However, the inadequate maintenance of the hydrotechnical works, the deposition of sediments, the dense vegetation in the streambeds and in some cases the inappropriate dimensions of technical works, have as a result the increase of the flood risk.

The protection of the environment constitutes the first priority when we are talking about NATURA habitats, which are extremely crucial for the maintenance of rare and endangered flora and fauna species. However, in NATURA areas various human activities take place and flooding constitutes a serious problem. Consequently, efforts should concentrate on protecting valuable and endangered habitat types while ensuring that flood risk in the area remains low. Vegetation management within the streams and next to hydrotechnical works is undoubtedly a complicated process, which requires relevant scientific expertise, time, light machinery and capital investment.

Special Ecological Evaluation studies aiming at the flood risk assessment and educating the public about the necessary flood control measures necessity and impact, could provide a framework for a thorough discussion about the flood management in NATURA areas. The Special Ecological Evaluation studies could be the outcome of the combined knowledge and efforts of the stakeholders, local authorities and the ecological groups of the area, as well as considering public consultation arguments.

Author Contributions: Conceptualization, A.K. and G.F.; methodology, A.K.; software, A.K.; validation, A.K., G.T. and G.F.; formal analysis, A.K.; investigation, G.T; G.F. and A.K.; data curation, G.T.; writing-original draft preparation, A.K. and G.T.; writing—review and editing, A.K., G.T. and G.F.; visualization, A.K.; supervision, G.F. All authors have read and agreed to the published version of the manuscript.

Funding: This research was funded by Society for the Protection of Prespa (SPP), as part of the LIFE15 NAT/GR/000936 Prespa Waterbirds project, funded by the EC and co-funded by the Prespa Ohrid Nature Trust (PONT), under grant number 34.0478 of Special Research Funds Account of the Agricultural University of Athens.

Data Availability Statement: The data that support the findings of this study are available from the corresponding author upon reasonable request.

Acknowledgments: The authors wish to thank the Society for the Protection of Prespa for the support.

Conflicts of Interest: The funders had no role in the design of the study; in the collection, analyses, or interpretation of data; in the writing of the manuscript, or in the decision to publish the results.

\section{References}

1. Belmonte, M.C.; Segura Beltrán, F. Flood events in Mediterranean ephemeral streams (ramblas) in Valencia region, Spain. Catena 2001, 45, 229-249. [CrossRef]

2. Bull, L.J.; Kirkby, M.J.; Shannon, J.; Hooke, J.M. The impact of rainstorms on floods in ephemeral channels in Southeast Spain. Catena 1999, 38, 191-209. [CrossRef]

3. Jodar-Abellan, A.; Valdes-Abellan, J.; Pla, C.; Gomariz-Castillo, F. Impact of land use changes on flash flood prediction using a sub-daily SWAT model in five Mediterranean ungauged watersheds (SE Spain). Sci. Total Environ. 2019, 657, 1578-1591. [CrossRef]

4. Norén, V.; Hedelin, B.; Nyberg, L.; Bishop, K. Flood risk assessment-Practices in flood prone Swedish municipalities. Int. J. Disaster Risk Reduct. 2016, 18, 206-217. [CrossRef]

5. Barredo, J.I. Normalised flood losses in Europe: 1970-2006. Nat. Hazards Earth Syst. Sci. 2009, 9, 97-104. [CrossRef]

6. Canuti, P.; Casagli, N.; Pellegrini, M.; Tosatti, G. Geo-hydrological hazard. In Anatomy of An Orogen: The Apennines and Adjacent Mediterranean Basins; Vai, G.B., Martini, I.P., Eds.; Kluwer Academic Publisher: Dordrecht, The Netherlands, 2001 ; pp. 513-532. [CrossRef]

7. Diakakis, M.; Deligiannakis, G.; Katsetsiadou, K.; Antoniadis, Z.; Melaki, M. Mapping and classification of direct flood impacts in the complex conditions of an urban environment. The case study of the 2014 flood in Athens, Greece. Urban Water J. 2017, 14, 1065-1074. [CrossRef] 
8. Llasat, M.C.; Llasat-Botija, M.; Prat, M.A.; Porcu, F.; Price, C.; Mugnai, A.; Yair, Y. High-impact floods and flash floods in Mediterranean countries: The FLASH preliminary database. Adv. Geosci. 2010, 23, 47-55. [CrossRef]

9. Barredo, J.I. Major flood disasters in Europe: 1950-2005. Nat. Hazards 2007, 42, 125-148. [CrossRef]

10. Diakakis, M.; Andreadakis, E.; Nikolopoulos, E.I.; Spyrou, N.I.; Gogou, M.E.; Deligiannakis, G.; Katsetsiadou, N.K.; Antoniadis, Z.; Melaki, M.; Georgakopoulos, A.; et al. An integrated approach of ground and aerial observations in flash flood disaster investigations. The case of the 2017 Mandra flash flood in Greece. Int. J. Disaster Risk Reduct. 2019, 33, 290-309. [CrossRef]

11. Faccini, F.; Luino, F.; Paliaga, G.; Sacchini, A.; Turconi, L. Yet another disaster flood of the Bisagno stream in Genoa (Liguria, Italy): 9-10 October 2014 event. Rend. Online Soc. Geol. Ital. 2015, 35, 128-131. [CrossRef]

12. Gaume, E.; Bain, V.; Bernardara, P.; Newinger, O.; Barbuc, M.; Bateman, A.; Viglione, A. A compilation of data on European flash floods. J. Hydrol. 2009, 367, 70-78. [CrossRef]

13. Gaume, E.; Borga, M.; Llasat, M.C.; Maouche, S.; Lang, M.; Diakakis, M. Mediterranean extreme floods and flash floods. Into Hydrometeorological extremes, The Mediterranean Region under Climate Change. A scientific update, 2016IRD Éditions Institut de Recherche pour le Développement. Marseille 2016, 133-144.

14. Guzzetti, F.; Stark, C.P.; Salvati, P. Evaluation of flood and landslide risk to the population of Italy. Environ. Manag. 2005, 36, 15-36. [CrossRef]

15. Jonkman, S.N.; Kelman, I. An analysis of the causes and circumstances of flood disaster deaths. Disasters 2005, $29,75-97$. [CrossRef] [PubMed]

16. Vinet, F.; Lumbroso, D.; Defossez, S.; Boissier, L. A comparative analysis of the loss of life during two recent floods in France: The sea surge caused by the storm Xynthia and the flash flood in Var. Nat. Hazards 2012, 61, 1179-1201. [CrossRef]

17. Barrera, A.; Llasat, M.C.; Barriendos, M. Estimation of extreme flash flood evolution in Barcelona County from 1351 to 2005. Nat. Hazards Earth Syst. Sci. 2006, 6, 505-518. [CrossRef]

18. Boithias, L.; Sauvage, S.; Lenica, A.; Roux, H.; Abbaspour, K.C.; Larnier, K.; Sánchez-Pérez, J.M. Simulating flash floods at hourly timestep using the SWAT model. Water 2017, 9, 929. [CrossRef]

19. Hooke, J.M. Geomorphological impacts of an extreme flood in SE Spain. Geomorphology 2016, 263, 19-38. [CrossRef]

20. Lara, A.; Saurí, D.; Ribas, A.; Pavón, D. Social perceptions of floods and flood management in a Mediterranean area (Costa Brava, Spain). Nat. Hazards Earth Syst. Sci. 2010, 10, 2081-2091. [CrossRef]

21. Angelakis, A.N.; Antoniou, G.; Voudouris, K.; Kazakis, N.; Dalezios, N.; Dercas, N. History of floods in Greece: Causes and measures for protection. Nat. Hazards 2020, 101, 833-852. [CrossRef]

22. Faccini, F.; Luino, F.; Paliaga, G.; Sacchini, A.; Turconi, L.; de Jong, C. Role of rainfall intensity and urban sprawl in the 2014 flash flood in Genoa City, Bisagno catchment (Liguria, Italy). Appl. Geogr. 2018, 98, 224-241. [CrossRef]

23. Marafuz, I.; Rodrigues, C.; Gomes, A. Analysis and assessment of urban flash floods on areas with limited available altimetry data (Arouca, NW Portugal): A methodological approach. Environ. Earth Sci. 2015, 73, 2937-2949. [CrossRef]

24. Myronidis, D.; Ioannou, K. Forecasting the urban expansion effects on the design storm hydrograph and sediment yield using artificial neural networks. Water 2019, 11, 31. [CrossRef]

25. Segura-Beltrán, F.; Sanchis-Ibor, C.; Morales-Hernández, M.; González-Sanchis, M.; Bussi, G.; Ortiz, E. Using post-flood surveys and geomorphologic mapping to evaluate hydrological and hydraulic models: The flash flood of the Girona River (Spain) in 2007. J. Hydrol. 2016, 541, 310-329. [CrossRef]

26. Kastridis, A.; Stathis, D. Evaluation of hydrological and hydraulic models applied in typical Mediterranean Ungauged watersheds using post-flash-flood measurements. Hydrology 2016, 7, 12. [CrossRef]

27. Borga, M.; Gaume, E.; Creutin, J.D.; Marchi, L. Surveying flash floods: Gauging the ungauged extremes. Hydrol. Process. 2008, 22, 3883-3885. [CrossRef]

28. Papaioannou, G.; Loukas, A.; Vasiliades, L.; Aronica, G.T. Flood inundation mapping sensitivity to riverine spatial resolution and modelling approach. Nat. Hazards 2016, 83, 117-132. [CrossRef]

29. Council Directive 92/43/EEC of 21 May 1992 on the Conservation of Natural Habitats and of Wild Fauna and Flora. Available online: https: / / eur-lex.europa.eu/legal-content/EN/TXT/?uri=celex\%3A31992L0043 (accessed on 5 September 2021).

30. Ministry of the Environment and Energy (YPEN) 2021. Framework of Priority Actions for the NATURA 2000 Network in Greece, in Accordance with Article 8 of Council Directive 92/43/EEC on the Conservation of Natural Habitats and of Wild Fauna and Flora (Habitats Directive) for the Period of Financial Framework 2021-2027. Available online: https://ypen.gov.gr/wp-content/ uploads/2021/04/PAF-EL_FINAL-2.pdf (accessed on 5 September 2021).

31. Kastridis, A.; Kamperidou, V. Influence of land use changes on alluviation of Volvi Lake wetland (North Greece). Soil Water Res. 2015, 10, 121-129. [CrossRef]

32. Maina, C.W.; Sang, J.K.; Raude, J.M.; Mutua, B.M.; Moriasi, D.N. Sediment distribution and accumulation in Lake Naivasha, Kenya over the past 50 years. Lakes Reserv. Res. Manag. 2019, 24, 162-172. [CrossRef]

33. Kastridis, A.; Stathis, D. The Effect of Small Earth Dams and Reservoirs on Water Management in North Greece (Kerkini Municipality). Silva Balc. 2015, 16, 71-84. Available online: https://silvabalcanica.files.wordpress.com/2015/09/sb_162-2015-071 -084.pdf (accessed on 12 July 2021).

34. Ashraf, M.; Kahlown, M.A.; Ashfaq, A. Impact of small dams on agriculture and groundwater development: A case study from Pakistan. Agric. Water Manag. 2007, 92, 90-98. [CrossRef] 
35. Vrahnakis, M.; Fotiadis, G.; Kazoglou, Y. Habitat Types of Prespa National Park, Record, Evaluation and Geographical Presentation; Society for the Protection of Prespa-TEI Larisas: Larisa, Greece, 2011; 124p. (In Greek)

36. Weigelhofer, G.; Feldbacher, E.; Trauner, D.; Pölz, E.; Hein, T.; Funk, A. Integrating Conflicting Goals of the EC Water Framework Directive and the EC Habitats Directives into Floodplain Restoration Schemes. Front. Environ. Sci. 2020, 8, 225. [CrossRef]

37. Kidová, A.; Radecki-Pawlik, A.; Rusnák, M. Hydromorphological evaluation of the river training impact on a multi-thread river system (Belá River, Carpathians, Slovakia). Sci. Rep. 2021, 11, 6289. [CrossRef] [PubMed]

38. O'Keeffe, J.; Marcinkowski, P.; Utratna, M.; Piniewski, M.; Kardel, I.; Kundzewicz, Z.W.; Okruszko, T. Modelling Climate Change's Impact on the Hydrology of Natura 2000 Wetland Habitats in the Vistula and Odra River Basins in Poland. Water 2019, 11, 2191. [CrossRef]

39. Tudose, N.C.; Ungurean, C.; Davidescu, S.; Clinciu, I.; Marin, M.; Nita, M.D.; Adorjani, A.; Davidescu, A. Torrential flood risk assessment and environmentally friendly solutions for small catchments located in the Romania Natura 2000 sites Ciucas, Postavaru and Piatra Mare. Sci. Total. Environ. 2020, 698, 134271. [CrossRef]

40. Strid, A.; Bergmeier, E.; Fotiadis, G. Flora and Vegetation of the Prespa National Park; Society for the Protection of Prespa: Agios Germanos, Greece, 2020.

41. Ministry of the Environment and Energy (YPEN) 2020. Areas of the European Ecological Network Natura 2000. Directorate of Natural Environment and Biodiversity Management. Available online: http://mapsportal.ypen.gr/maps/826 (accessed on 5 September 2021).

42. Institute of Geology and Mineral Exploitation (IGME). Engineering Geological Map of Greece, Scale 1:500000; Engineering Geology Department: Athens, Greece, 1993.

43. Hydrognomon. A Database System for the Management of Hydrometeorological Stations and Time Series. Hydrological Time Series Analysis and Processing Software Application. 2012. Available online: http:/ /hydrognomon.org (accessed on 7 May 2021).

44. Koutsoyiannis, D. Statistical Hydrology, 4th ed.; National Technical University of Athens: Athens, Greece, 1997; ISBN 978-960-603507-4. [CrossRef]

45. Moriasi, D.; Arnold, J.; Van Liew, M.; Bingner, R.; Harmel, R.; Veith, T. Model evaluation guidelines for systematic quantification of accuracy in watershed simulations. Trans. ASABE 2007, 50, 885-900. [CrossRef]

46. Singh, J.; Knapp, H.V.; Arnold, J.; Demissie, M. Hydrological modeling of the iroquois river watershed using hspf and swat1. J. Am. Water Resour. Assoc. 2005, 41, 343-360. [CrossRef]

47. Soil Conservation Service (SCS). National Engineering Handbook, Section 4; U.S. Department of Agriculture: Washington, DC, USA, 1972.

48. United States Department of Agriculture (USDA). Information on Rainfall, Frequency, \& Distributions. SCS Rainfall Distributions, Time Transformations. Transforming 24-h SCS Rainfall Distributions to Shorter Durations. 2021. Available online: https: //www.nrcs.usda.gov/wps/portal/nrcs/detailfull/national/water/?cid=stelprdb1044959 (accessed on 22 August 2021).

49. Mitra, S.S.; Wright, J.; Abhisek, S.; Ghosh, A.R. An integrated water balance model for assessing water scarcity in a data-sparse interfluve in eastern India. Hydrol. Sci. J. 2015, 60, 1813-1827. [CrossRef]

50. Rezaei-Sadr, H. Influence of coarse soils with high hydraulic conductivity on the applicability of the SCSCN method. Hydrol. Sci. J. 2017, 62, 843-848. [CrossRef]

51. Steenhuis, T.; Winchell, M.; Rossing, J.; Zollweg, J.A.; Walters, M. SCS runoff equation revisited for variable-source runoff areas. J. Irrig. Drain. Eng. ASCE 1995, 121, 234-238. [CrossRef]

52. Van Dijk, A.I.J.M. Selection of an appropriately simple storm runoff model. Hydrol. Earth Syst. Sci. 2010, 14, 447-458. [CrossRef]

53. Verma, S.; Verma, R.K.; Mishra, S.K.; Singh, A.; Jayaraj, G.K. A revisit of NRCS-CN inspired models coupled with RS and GIS for runoff estimation. Hydrol. Sci. J. 2017, 62, 1891-1930. [CrossRef]

54. Papaioannou, G.; Efstratiadis, A.; Vasiliades, L.; Loukas, A.; Papalexiou, S.M.; Koukouvinos, A.; Tsoukalas, I.; Kossieris, P. An Operational Method for Flood Directive Implementation in Ungauged Urban Areas. Hydrology 2018, 5, 24. [CrossRef]

55. Kastridis, A.; Kirkenidis, C.; Sapountzis, M. An integrated approach of flash flood analysis in ungauged Mediterranean watersheds using post-flood surveys and unmanned aerial vehicles. Hydrol. Process. 2020, 34, 4920-4939. [CrossRef]

56. Sapountzis, M.; Kastridis, A.; Kazamias, A.-P.; Karagiannidis, A.; Nikopoulos, P.; Lagouvardos, K. Utilization and uncertainties of satellite precipitation data in flash flood hydrological analysis in ungauged watersheds. Glob. Nest J. 2021, 23, 388-399. [CrossRef]

57. Soulis, K.X.; Ntoulas, N.; Nektarios, P.; Kargas, G. Runoff reduction from extensive green roofs having different substrate depth and plant cover. Ecol. Eng. 2017, 102, 80-89. [CrossRef]

58. Kaffas, K.; Hrissanthou, V. Application of a continuous rainfall-runoff model to the basin of Kosynthos river using the hydrologic software HEC-HMS. Glob. NEST J. 2014, 16, 188-203.

59. Stathis, D.; Sapountzis, M.; Myronidis, D. Assessment of land use change effect on design storm hydrograph using the SCS curve number method. Fresenius Environ. Bull. 2010, 19, 1928-1934.

60. Bournas, A.; Baltas, E. Comparative Analysis of Rain Gauge and Radar Precipitation Estimates towards Rainfall-Runoff Modelling in a Peri-Urban Basin in Attica, Greece. Hydrology 2021, 8, 29. [CrossRef]

61. Hydrologic Modeling System HEC—HMS User's Manual, Version 4.2; US Army Corps of Engineers, Hydrologic Engineering Center: Davis, CA, USA, 2016.

62. Chow, V.T.; Maidment, D.R.; Mays, L.W. Applied Hydrology; McGraw-Hill: New York, NY, USA, 1988 ; p. 572. 
63. Efstratiadis, A.; Koutsoyiannis, D.; Mamassis, N.; Dimitriadis, P.; Maheras, A. Literature Review of Flood Hydrology and Related Tools, DEUCALION-Assessment of Flood Flows in Greece under Conditions of Hydroclimatic Variability: Development of Physically-Established Conceptual-Probabilistic Framework and Computational Tools. Available online: https://www.itia.ntua. gr/getfile/1215/1/documents/Report_WP3_1_1.pdf (accessed on 25 November 2020).

64. Efstratiadis, A.; Koussis, A.D.; Koutsoyiannis, D.; Mamassis, N. Flood design recipes vs. reality: Can predictions for ungauged basins be trusted? Nat. Hazards Earth Syst. Sci. 2014, 14, 1417-1428. [CrossRef]

65. Michailidi, E.A.; Antoniadi, S.; Koukouvinos, A.; Bacchi, B.; Efstratiadis, A. Timing the time of concentration: Shedding light on a paradox. Hydrol. Sci. J. 2018, 63, 721-740. [CrossRef]

66. Giandotti, M. Previsione delle piene e delle magre dei corsi d'acqua. Ministero LL.PP. In Memorie e Studi Idrografici; Servizio Idrografico Italiano: Rome, Italy, 1934; p. 13. (In Italian)

67. United States Department of Agriculture (USDA). Time of Concentration. In Hydrology, National Engineering Handbook; Owens, L., Ed.; Part 630, Charpter 15; Natural Resources, Conservation Service, Conservation Engineering Division: Washington, DC, USA, 2010.

68. Manning, R. On the flow of water in open channels and pipes. Trans. Inst. Civil Eng. 1891, 20, 161-207.

69. HEC—RAS River Analysis System User's Manual, Version 4.1; US Army Corps of Engineers, Hydrologic Engineering Center: Davis, CA, USA, 2010.

70. De Jong, C. European perspectives on forest hydrology. In Forest Hydrology: Processes, Management and Assessment; Amatya, D., Williams, T., Bren, L., De Jong, C., Eds.; CABI: Wallingford, UK, 2016; pp. 69-87.

71. Anagnostou, M.N.; Kalogiros, J.; Marzano, F.S.; Anagnostou, E.N.; Montopoli, M.; Picciotti, E. Performance evaluation of a new rain microphysics algorithm for dual-polarization X-band radars using long-term radar and disdrometer measurements. $J$. Hydro-meteorol. 2013, 14, 560-576. [CrossRef]

72. Andreadakis, E.; Diakakis, M.; Vassilakis, E.; Deligiannakis, G.; Antoniadis, A.; Andriopoulos, P.; Spyrou, N.I.; Nikolopoulos, E.I. Unmanned Aerial Systems-Aided Post-Flood Peak Discharge Estimation in Ephemeral Streams. Remote Sens. 2020, 12, 4183. [CrossRef]

73. Marchi, L.; Borga, M.; Preciso, E.; Gaume, E. Characterization of selected extreme flash floods in Europe and implications for flood risk management. J. Hydrol. 2010, 394, 118-133. [CrossRef] 